\title{
Ishak Score 1-2
}

National Cancer Institute

\section{Source}

National Cancer Institute. Ishak Score 1-2. NCI Thesaurus. Code C157159.

Portal fibrosis is present. 